\title{
MOC KRZYŻA ŚWIĘTEGO Uwagi z teologii III wieku
}

W zestawie tez chrystologlcznych, Jak1 spotykamy w nlewielkim plámie św.Cypriana z Kartaginy "Ad Quirinum testimoniorum libri tres", poruszony jest równtez temat mocy płynącej z męki 1 znaku Krzyza Chrystusowego. Syntetycznte sformułowana teza, ze "w mece 1 znaku krzyża tkw1 cała moc 1 wadza"1, jest powiqzana z trzema starotestamentalnym1 cytatami biblijnymi egzegetowanymi według przekładu starej "Afry"/Ha 3,3-5; Iz 9,5; WJ 17,9,11-14/ 1 w oparc1u - nie rozpracowana. Trzeba tu dla uzupeznienia dodać, ze cała II ksiegga tego dzieła jest jedynym w swolm rodzaju compendium chrystologlcznym, Jakie dotarło do naszych czasów. Jego wyjatkowość polega na bardzo bogatym zestawie materiału biblifnego, pogrupowanego wokół różnych tematów teologicznych. Wyraża się tyon zreszta zasadnicza myśl Kościoła starozytnego, w Ĺtórym punktem wyjścla $i$ w ogóle rdzentem całej refleksji teologicznej było słowo objawiono na kartach Pisma św., historia zaś rozioju doktryny nie oznaczała niczego innego, jak historie egsegezy pewnej określonej grupy tekstów biblijnych. Równiez zasygnalizowany powyżej temat - nie tracazcy nigdy na swej aktualności - nie mógł pozostad bez zakorzenienia w myśl1 biblifnoj. Przez niniejsze uwagl chcielibysmy przynajmniej przyblizy of niektóre aspekty $z$ dość specyficznego klimatu myśli teoloficznej III w. 1 z trudnych niekiedy do zrozumienia pewnych órozesnych niuansów egzegetycznych.

Pierwszy enagment, w którym Cyprian dostrzegał zapowiodí mocy krzyża, pochodzi z prorockiej wizji nadojścia Boga, zblizajacego sie $z$ Góry synaj od strony Paranu². Przyjóclu temu towarzyszy grałtowne

1 Cyprianus, Ad Quirinum II 21, CC 3,59: "Quod in passione cructs et signo virtus omis sit et potestas".

2 Ha 3,3-5 redlug przokazu Cypriana/CC 3,59/: "Texit caolos virtus efus et laudis olus plena ost terra; et splendor elus ut lux orit, cornua in manibus eius erunt. bi lilic constabilita est virtus 
poruszente się sit przyrody, nzowykła swiatłość 1 potega majostatu. Decydujacyio jednak notywem, ze wzglęlu na który cytat ten odniesiony jest do krzyza Chrystusovego, saz głowa: "rogl bqua w jogro dłoniach" w połaczentu z uzupexntenter: "w nich spoczywa moc jego chrazy". Jest to ta sama "moc, która rozciaga niebiosa". Trzeba pamietać, ze "rogi" naleta do pierwotnych elgur krzyza; ternin ten bowiom odnoszony do rogów zwlerzęcych lub symbolizujący nieodpartá moc, stosowany byz w chrześcijaństwie dwóoh plexwszych wieków równiez na oznaczente poprzecznej belk1 krzyza. Laczony jest on także z 1nnym symbolem krzyza, zaczorpnlętym z tematyki żeglarsisiej, a mianowicle z poprzecznz belka masztu okrętowego, która w sumie tworzy kontury krzyza. Myśl ta znana była w środowiskach chrześcijariskich poczynaJąc od wypowlodzs. Justyna aż po śwladectwo ojców vI wieku ${ }^{3}$. Cały alscent tef figury o "rogach" spoczywa na ujawnianiu sie nieodpartef mocy krzyża w porząuku zbawienja". Chrystus ukrzyzowany zwisa z "rogów" - z belk1 swojego krzyza, ta zaś stanowi "tropaion" zbawienta, tzn. zwycięski znak zbawienia. Równieź św. Augustyn jage po tej linil odwoływał sie do tekstu Ilabakuka $/ 3,4 /$ i stwierczaz: "nogi w Jego dłoniach" - cóz to nozo byé innogo, jak nie zwyciaski znak krzyza" 5 . 'Takzo tekstow Izajasza /9,5/ przypisywali egzegeci starozytni nie inniej bogate znaczenie; mówıł zaś on o narodzeniu wyczekiwanego dzlec1ycla, na którogo ramionach spooznie włalza ${ }^{6}$. Przez sam lakt zestawienia tego cytatu z toza o nocy krzyża, Cyprian odniósł go do whalzy wynlkajłcej z mękı Chrystusa. Aby jednak uchwycic głębszy sens tego tekstu, warto sie równiez odwołać do wypowiedzi innych

glorlac eius, et constituet dilectionem validar. Ante faciem suam lbit verbun et procedat in campos sccundum gressus suos".

3 Por. Il. Raliner, Locclesiologia dol Padri. Siaboll della Chiesa, lloma $1971,611-690$; J.Daniélou, Théologio du Judéo-Christianisme, Paris 1958, 200-315.

4 Por. Justinus, Dialogus cum Tryphone 91, PG 6,693, POK 4,265-267. 5 De civitate De1 XVIII, 32, CSLL 40,2,313: "Cornua in manibus e1us sunt, quid est nisi tropaoum crucis".

6 Iz 9,5 wedlug przokazu Cypriana/Ad Quirinum II 21, CC 3,59/: "Eces natus est vobis puer, et datus est nobls filius, culus imperiun super humeros eius". 
autorów w tej inateri1. Ireneusz z Lyonu wyjaśnia, ze chodz1 tu - Pigurę zapowladająca krzyz, do którego będa przygwozdżone ramiona przepowiadanego ksį̧cia. Krzyż rzeczywistości podkreśla moc Chrystusa, jest on znaklem Jego królewskości ${ }^{7}$. Tertulian zaś odnośnie do tego tekstu wyjaśniał: "Nowy Król wieków, Jezus Chrystus, niesie na swolch ramionach nowa chwałe, władze 1 doskonałośc czyli krzyz, gdyź... Pan zaczał królować z drzewan 8 .

Trzeciemu wreszcie cytatowi z Ksieg1 Wyjścia $/ 17,9,11-14 /^{9}$ Cyprian wprost nadal interpretacje teologiczna 1 związał go z krzyzem: "Poprzez znak krzyża Amalekita został pokonany przez Jozuego dzięi Mojzeszow 10 . Cytat biblijny przedstawia zwyciestwo Jozuego nad Amalekitami, odntestone dz1ęk1 wstawienniczej modlitwie Mojżesza, trwajacego przez cały czas walki ze wzniesionymi do góry ramionami. Rozłoźone ramiona modlazcego sle Mojzesza uobecniały w dalszej antycypacji, zdaniem Cypriana, znak krzyza Chrystusa. Cała jego argumentacje wzmacnia jeszcze typologia Chrystusa w osobie Jozuego, którego 1mlę juź w plerwszych wiekach Kościoła czytane było w transkrypcji łacińskiej jako "Iesus"; ukatwiało to niewatpliwio naszemu B1skupori tego rodzaju interpretacje ${ }^{11}$. Moc krzyza Chrystusowego, który zniszczył szatana, jest tak wielka, ze oddzlałuje on takze poprzez swą zapowledź w modliternym geścio Mojzesza. Tak1 tok rozumowania staje sie jeszcze bardziej oczyisty, gdy sobie uśwa-

7 Por. Irenaus, Epldeixis, 56, $\operatorname{SCh} 62,119$.

8 Adversus Iudacos 10,11, CC 2,1378: "... novus rex/novorum/ aevorum, Christus Iesus, novam glorian et potestatem et subl1mitatem suam in humero extulit, crucern scilicet, ut secundum... prophetiam exinde Dominus regnaret a ligno".

9 WJ 17,9,11-14 wedlug przekazu Cypriana/Ad Quirinum II, 21, CC 3,59-60\%: "Elige tibi viros, et exi, et constitue cum Amalech in crastinum. Fcco ogo stabo in cacumine collis, et virga Del in manu mea. Et factum est cum levabat manus soyses, praevalebat Israel; ub1 autem submiserat manus Moyses, invalescebat Amalech. Sed manus Moysi erant graves, et accepto lapide supposuerunt sub eo, et sedebat super eum; et Aaron et Or sustentabant manus eius hinc et inde, et factae sunt manus Moysi stabiles usque in occasur solis, et fugavit Jesus Amalech ot omnem populum eius".

10 Ad Quirinum II 21, CC 3,59: "lloc signo crucis et Adalech victus $\theta$ t ab Iesu per Moysen".

11 Podstawe do takiej typologil stanowilo nie tylko $1 \mathrm{~m} 1 \mathrm{e}$ "Iesus", "Jeshua", lecz takze wprowadzente przez Jozuego narodu wybranego do ziemi oblecanej. Zob. J.Daniélou, Sacramentum futuri. Bcudes 
domimy, ze Amalekita uchodziz za personifikacje szatana ${ }^{12}$. Epizod ow stanowi jeden z przykładów ujawniania się jeszcze w pazle starotestanentalnej ekonomid zbawienia, określanej przez biskupa Kartaginy jako "virtus insigno crucis".

$\mathbb{W}$ rozpatrywanym więc notymie, objętym przez "tajemnice Chrystusa" Cyprian pragnąz wyeksponować moc Chrystusa w jej aspekcie soteriologleznym. Ta moc, która wskazuje równoczé́nie na jego królenskośc, zaczyna ukazywać słę w krýcu: narzędzie męk1 staje się znakien tryunfu 1 mocy. Siła krzyza jest tak njeograniczona, zo ujawnia sia nawet " jego prefigurach $i$ zapowiedziach, jak to mialo miejsce w wyadku Mojzesza.

$$
\text { Ks. Tomasz Kaczmarek - Włocławek }
$$

DE virtute aC potestate ciadeis

Hoc in brevissimo articulo virtus ac potestas crucis, quae tribus Sacrae Soripturae locis/Hab. 3,3-5; Is.9,5; Exod. 17,9,1114/ a Cypriano Carthaginens1 interpretatis expressae sunt, exponuntur.

sur les orlgines de la tipologie biblique, Paris 1950, 205.

12 Por. Cyprianus, Ad Quirinum II, 16, CC 3,52: "Amalech superatus ost ab Iesu, 1d est diabolus a Christo victus est". 